\title{
Judge Specific Differences in Chapter 11 and Firm Outcomes
}

\author{
Tom Chang \\ and \\ Antoinette Schoar ${ }^{1}$
}

November 24, 2008

${ }^{1}$ MIT; MIT Sloan School of Management, NBER and CEPR. Michael Sugar, Michael Altemin, Dwayne Kennemore, Rachel Shaw, Stewart Park, Suhitha Reddy, Iraklis Sbarounis and Wendy Wen provided outstanding research assistance. We thank Bernard Black, Glenn Ellison, Stuart Gilson, Edith Hotchkiss, Lynn LoPucki, Judge James Massey, Sendhil Mullainathan, Nancy Rose, Karen Thorburn, Ivo Welch and participants at the AFA and ALEA annual meetings, NBER Summer Institute, Financial Contracting: Theory and Evidence conference and seminar participants at CREST, Dartmouth, ERIM, Harvard, HBS, HEC School of Management, Kellogg School of Management, MIT, Oxford, Ross School of Business, and UCLA Anderson School of Business. 


\begin{abstract}
This paper uses case information on Chapter 11 filings for almost 5000 private companies across five district courts in the US between 1989 and 2004. We first establish that within districts cases are assigned randomly to judges, which allows us to estimate judge specific fixed effects in their Chapter 11 rulings. We find very strong and economically significant differences across judges in the propensity to grant or deny specific motions. Specifically some judges appear to rule persistently more favorably towards creditors or debtors. Based on the judge fixed effects we created an aggregate index to measure the pro-debtor (procreditor) friendliness of each judge. We show that a pro-debtor bias leads to increased rates of re-filing and firm shutdown as well as lower post-bankruptcy credit ratings and lower annual sales growth up to five years after the original bankruptcy filing.
\end{abstract}




\section{Introduction}

Chapter 11 of the U.S. bankruptcy code aims to provide court protection to distressed firms that are economically viable in order to avoid inefficient liquidation and maintain firms as going concerns. It has been praised as one of the cornerstones of effective company restructuring in the US. ${ }^{1}$ Indeed, many countries have tried to emulate the US system of Chapter 11 in order to provide companies with a fresh start and encourage entrepreneurship. Yet the recent surge in bankruptcy filings in the US and the lengthy process of Chapter 11 resolutions has rekindled the discussion about the optimality of the Chapter 11 process.

An efficient bankruptcy process has to strike a delicate balance. On the one hand it must give creditors enough tools to preserve the bonding role of debt by penalizing managers and shareholders adequately for poor performance, prevent inefficient continuation of nonviable companies and preserve the incentives for entrepreneurs to repay their debts. On the other hand, the process should allow management to prevent inefficient liquidation and asset stripping by creditors when the firm is viable as a going concern. Hart (1999) discusses these goals of an efficient bankruptcy procedure and points out the inherent tension between them in designing of a bankruptcy regime. This tradeoff is based on two types of inefficiencies that can arise in the negotiations between the different claim holders. ${ }^{2}$ Since debt holders do not participate in the upside of the firm, the interest of debt holders is to preserve the collateral value of the firms assets rather than allowing new, risky investments. Moreover, given that debt holders are senior in liquidation, they have a claim on any additional investment that is made. This also can lead to underinvestment and inefficient liquidation once the firm is in distress, since effectively the old claimholders constitute a tax on any new investor, as pointed out by Myers' (1977) debt overhang argument. In contrast, equity holders favor overinvestment and inefficient continuation; due to limited liability they benefit from risk

\footnotetext{
${ }^{1}$ As cited in Smith and Stromberg (2005), the United Kingdom, Japan, Germany, France and Sweden have all recently instituted 'more debtor-friendly, U.S. styled reorganization codes into their bankruptcy laws.... Indeed, the World Bank, International Monetary Fund (IMF), and the European Union (EU) now encourage member countries to adopt bankruptcy laws that have a reorganization code as one of their cornerstones.'

${ }^{2}$ See for example Gertner and Sharfstein (1991) for a theoretical analysis of the incentives of debt and equity claims in Chapter 11 resolutions.
} 
shifting a la Jensen and Meckling (1976). This view of firm restructuring would predict that a change towards a more debtor friendly regime (which gives more bargaining power to debt holders) leads to more continuation and investment while a more creditor friendly regime leads to more liquidation.

In this paper we test whether this basic hypothesis reflects the reality of how changes in the bargaining power of either creditors or debtors affect resolutions of Chapter 11 in the US. Surprisingly our findings are exactly opposite to the simple tradeoff laid out in previous paragraph. Indeed contrary to the simple theory, we find that increasing the debtor friendliness of the current Chapter 11 process leads to an increase in firm shut downs, higher re-filing rates and lower credit ratings and sales growth of the firms that survive Chapter 11. We find the opposite results for an increase in the creditor friendliness. These findings suggest that on average creditors rather than debtors seem to be the ones who are pushing for restructuring solutions in Chapter 11 that allow for more successful continuation of the firm.

The challenge in testing the causal impact of the debtor (creditor) friendliness of the bankruptcy process is to find exogenous variations in the bankruptcy environment, since observed bankruptcy rulings and outcomes could be simultaneously driven by unobservable characteristics such as the difficulty of the case. In this paper we exploit the large heterogeneity among US bankruptcy judges in their interpretation of the bankruptcy laws as an instrument for the debtor (creditor) friendliness of the bankruptcy environment that a company faces in Chapter 11. We can estimate these fixed effects in a meaningful way since, both court procedure and our analysis of the data, show that cases are randomly assigned to judges. While bankruptcy law is set at the federal level, we show that the interpretation (application) of the law varies largely across judges. Among the judges in our sample there are significant differences in the likelihood of granting or denying motions that favor either creditors or debtors. In fact, we find a strong systematic pattern that judges either tend to rule in favor of or against creditors across all types of motions. These findings suggest that the particular judge that a firm draws in Chapter 11 is a significant determinant for 
how the laws are applied. We can therefore use the specific judge as a proxy for whether the Chapter 11 process is marginally more (less) tilted towards the debtor or the creditor. The existence of robust judge fixed effects is consistent with Bris, Welch and Zhu (2006) and their discussion of the existence of 'behavioral difference among judges.' Using more detailed case information on a smaller number or cases, they find statistically significant differences across judges 'in terms of the fraction that they pay out to creditors, how they adhere to APR, and how many days the proceedings take.'

We then use these estimated judge fixed effects to build an index which classifies the debtor or creditor friendliness of a given judge across all his rulings in Chapter 11 . We classify any motions as pro-debtor that aim to prevent asset stripping and encourage followon investment to maintain the firm as a going concern. Specifically (D1) the automatic stay, which prevents secured creditors from taking out their asset from the firm and ensures that all debt service to the creditors is withheld. (D2) The exclusivity period which mandates that during the first 120 days of bankruptcy, only the debtor can submit a restructuring proposal. After the first 120 days the judge can either extend the exclusivity period or allow creditors to submit their own proposal. (D3) Use of cash collateral, which gives the judge the authority to grant debtor in possession to use cash collateral to maintain the firm as a going concern. Vice versa we classify a judge as pro-creditor if he or she scores high on motions that allow creditors to maintain their asset value, e.g. lifting the automatic stay, granting the conversion to Chapter 7 or denying the extension of the exclusivity period.

This index allows us to analyze the marginal impact of a move towards a more debtorfriendly (or creditor-friendly) Chapter 11 workout. As discussed before, we would expect that a firm which is allocated to a judge who scores low on the pro-debtor index should lead to less continuation (even efficient continuations), since creditors care for the protection of their assets. In contrast, equity benefits most when the firm survives as a going concern and thus a pro-debtor environment should show a higher rate of continuation. We actually find the opposite: An increase in the debtor friendliness of the workout environment leads to higher shut down rates and more re-filings of firms after coming out of Chapter 11. 
Moreover, we find worse outcomes post-Chapter 11 for those firms that were restructured in a pro-debtor workout environment. These firms show a greater decrease in sales and employment level in the years following Chapter 11 relative to firms with pro-creditor judges and a worsening credit rating going forward.

These findings are very surprising: Bankruptcy workouts where the creditors have more power relative to those where the debtors have more power increase the likelihood of continuation and show better performance ex post. This outcome is not mechanically driven by survivorship bias, i.e. that pro-creditor judges have a higher hurdle rate in whom they let through Chapter 11 and thus the few surviving firms are of better quality. To the contrary, we find that fewer firms are shut down in Chapter 11 under a pro-creditor judge.

What can explain these counter-intuitive results?

One interpretation is a governance failure in firms that enter distress; in particular equity is not adequately represented by management in the bankruptcy process. Governance problems between shareholders and management might result in the destruction of assets in the bankruptcy process, since management might use the process not to restructure the firm in the interest of shareholders but to use the Chapter 11 process maximize their private rents. For example, Weiss and Wruck (1993) argue in the context of the Eastern Airlines bankruptcy that a debtor friendly bankruptcy judge allowed for excessive asset stripping to prevent the shut-down of the firm. Additional empirical support for this argument comes from Betker (1995), who provides evidence that management uses its ability to draw out the bankruptcy process as leverage in negotiations with creditors, at times to the detriment of equity.

Alternatively, if equity has the de facto control rights, a restructuring process that is tilted towards debtors could allow equity itself to extract financial resources from the firm (instead of keeping assets tied up in firm). Owner-managers who are in control of day-today management would be able to take the most important assets or human capital out of the firm and thus avoid having to share future income with existing claim holders. For example extending the exclusivity period, or allowing the use of cash collateral and asset 
sales, may allow equity holders to circumvent creditors and pay themselves in bankruptcy. If this extraction technology for equity is not too costly, maintaining the firm as a going concern might not be the most attractive option. In contrast, (unsecured) creditors cannot engage in this type of behavior since they do not have de facto control rights in the firm, and thus have to preserve the firm as a going concern.

Our results suggest that ignoring these important governance implications in the analysis of firm restructuring can result in policy recommendations that lead to conunter-intuitive results. In situations where agency problems within firms are particularly severe, equity holders and minority shareholders might be better protected by creditors rather than management in times of distress.

Finally we want to be cautious to delineate what we can and cannot say about the efficiency of the bankruptcy process based on the findings in this study. Our identification strategy allows us to shed light on how a change in the debtor (creditor) friendliness of the workout process in Chapter 11 affects the ex post performance of distressed firms. However, we cannot say anything about the ex ante incentive effects of a change towards a more creditor (debtor) friendly judge, since the identity of the judge is not known to the parties at the time they write contracts, or make lending decisions.

\subsection{Literature Review}

Our paper contributes to the debate about Chapter 11 in a number of ways. First we provide a novel instrument to estimate the causal impact of greater debtor (creditor) friendliness for the workout process between creditors and debtors. These findings build in on the earlier literature starting with Hotchkiss (1995) who looks at the performance of 197 public companies post Chapter 11 and finds little evidence that the process effectively restructures distressed firms. She concludes that it is consistent with the view that "there are economically important biases towards continuation of unprofitable firms." Firm performance in the three years following bankruptcy was worse if management was not replaced. For a similar conclusion see Gilson (1993). On the other hand Baird and Rasmussen (2002) and Skeel (2003) argue that contractual developments have allowed creditors to "neutralize" 
inefficiencies due to the pro-debtor nature of Chapter 11, and that creditors "have managed to undue such biases through private contracting." 3

Internationally, Thorburn (2000) finds that Sweden's more creditor friendly auction based bankruptcy system leads fewer deviations from absolute priority, lower cost, and are resolved faster than the U.S. Chapter 11 cases. In contrast Ravid and Sundgren (1998) examine the relative efficiency of the "creditor-oriented old Finnish bankruptcy code and the debtor-oriented US code" and finds that U.S. reorganizations are more efficient.

The role of agency issues between equity holders and managers in Chapter 11 has been widely investigated in the law literature. For example, Bradley and Rosenzweig (1992) suggest that "bankruptcy law fails to provide managers with appropriate incentives to allocate corporate resources to their highest-valued uses, but instead rewards managers for taking inefficiently high risks. Betker (1995) argues that management has the real control in Chapter 11 and their interests are not always aligned with their shareholders. He provides some empirical evidence to support his idea by looking at cases where CEO pay and shareholder wealth were negatively related and show that management incentives correlate with violation of absolute priority. Eckbo and Thorburn (2003) show that reputation effects temper CEO taste for excessive risk taking in Swedish automatic bankruptcy auctions. Franks and Torous (1994) compare creditor recovery rates during distressed exchanges and Chapter 11 reorganizations. They find creditors have lower recovery rates in Chapter 11, and argue that there is a high cost (to creditors) to formal reorganization.

Among others, Berglof and von Thadden (1994), Dewatripoint and Tirole (1994) and Bolton and Scharfstein (1996) find that in a world of incomplete contracts, having multiple creditors (or investors) can lead to increased ex ante efficiency at the cost of ex post efficiency. Kahl (2002) argues that the poor performance of firms post debt-restructuring is not due to coordination problems among creditors, or an inefficient bankruptcy process, but instead are simply the result of the dynamic learning strategies of creditors. Ayotte

\footnotetext{
${ }^{3}$ Skeel (2003) specifically sites the "use of debtor-in-possession financing agreements as a governance lever; and the so-called pay-to-stay arrangements which give key managers bonuses for meeting specified performance goals" as the two key contractual developments since the 1980s.
} 
(2007) examines a model of bankruptcy for entrepreneurial firms, and suggests that when the value of the firm as a going concern is dependent on the effort of an owner-manager, expost efficiency is best served by a "fresh start" for the indebted entrepreneur. The current paper shows that the objectives of equity holders seem to be more effectively represented by creditors than by management, because of governance problems within the firm.

More directly relevant to our paper is the role of individual bankruptcy judges and their influence over bankruptcy cases. In an analysis closest to our own in terms of the methodology and data, Bris, Welch and Zhu (2005) find significant behavioral differences across judges in terms of the fraction paid out to creditors, adherence to absolute priority, and case length. LoPucki and Whitford (1993) state that with the level of discretion afforded bankruptcy judges, "a skilled, aggressive bankruptcy judge who wished to do so could wield virtually complete power over the governance of a reorganizing company. Based on interviews and independent analysis, LoPucki and Whitford concluded that in over a quarter of the cases in their sample, the judge did indeed choose to play a "major role in the case. To quote from Aghion, Hart and Moore (1992) "placing decisions in the hands of representatives - and indeed the supervising judge - creates agency problems... Judges too can use their supervisory powers to pursue their own agendas, which may be in conflict with the claimants' narrow objective of value maximization.

\subsection{Identification Strategy}

To undertake this study, we collected information on all Chapter 11 filings of small businesses in six US district courts: Arizona, California (LA), California (ND), California (RS), California (SA), California (SV), Delaware, Northern Georgia, and New Jersey. ${ }^{4}$ Ultimately we obtain a sample of 4857 cases across 59 judges. The data was collected from the PACER (Public Access to Court Electronic Records) web sites. Started in 1990, PACER was Federal Judicial Conferences response to a Congressional Mandate to provide reasonably priced public access to court records in electronic form. For each case we coded the most important decisions (motions and rulings) that the judge ruled on during the Chapter 11 hearings. For

\footnotetext{
${ }^{4}$ We are currently in the process of extending the data to more than 60 additional district courts.
} 
example, we code whether the lifting of an automatic stay was granted or denied, whether the use of cash collateral was granted or denied, whether the judge decided to convert the case into another chapter, etc. To be able to handle the enormous volume of this task the coding was done through a computerized algorithm and then cross checked by hand to validate the findings. We supplement this information with data from Dun \& Bradstreet on the observable characteristics of the firms that are filing for Chapter 11.

It is important to note that our identification strategy relies crucially on the assumption that cases are randomly assigned to judges in Chapter 11. However, we are not imposing random assignments across different bankruptcy courts, but just between judges within a given district court. This assumption seems well in line with the provisions of the law. While a large literature has shown that there seems to be significant forum shopping across jurisdictions, judge shopping is widely condemned and actively discouraged, see for example Eisenberg and LoPucki (1999). The bankruptcy courts within our sample state that they are using a random assignment rule to allocate cases to judges. Moreover, our empirical tests corroborate this assumption.

We first verify that firms indeed are randomly allocated to firms. For that purpose we show that there are no significant difference in the sales, number of employees or credit rating of cases across judges. The F-tests on the judge fixed effects show that there are no significant fixed effects in the observable characteristics of Chapter 11 cases that judges are assigned to. When we redo these tests at the district by district level we find that random assignment holds in all district courts, but we have some suggestive evidence that it is less strong in Delaware. However, the results for Delaware might be less representative since Delaware has a very large number of pre-pack Chapter 11 filings which we cannot include in our estimation since there are no data available through PACER on the rulings or outcomes in these cases. Throughout the paper we therefore make sure that all our results hold when we exclude Delaware from the sample.

In the second step we repeat a similar set of regressions for the different rulings of judges in Chapter 11, for example granting or denying the lift of an automatic stay, the use 
of cash collateral, the dismissal of the case. One by one we regress the judges decisions on a set of judge fixed effects and district times year effects. We find that there are significant differences in how judges rule in Chapter 11. We find a significant F-test for almost all of the judges' decisions. In particular we find strong differences on some of the more prominent decisions such as granting or denying the lifting of an automatic stay or allowing the use of cash collateral. The results do not change if we include firm level controls for size, number of employees or industry, as suggested by the random assignment results established above. These findings are quite remarkable since they suggest that judges indeed differ systematically in their likelihood to rule in favor of creditors or debtors in Chapter 11.

For the interpretation of our results it is important to note that while we show that cases seem to be randomly assigned to judges in Chapter 11, the different parties in bankruptcy, especially the lawyers who representing the creditors or the management, might know the reputation of the judge to which they were assigned. Given their expectation of succeeding with a specific motion, the different parties in bankruptcy might endogenously choose whether or not to file a motion in the first place. Take the case of a very strict judge who is known to only very rarely allow an extension of exclusivity or to lift an automatic stay. In that case the lawyers of the different parties in bankruptcy might not even try to file a certain motion, since they expect rejection and vice versa in the case of a judge who is considered more permissive. Therefore, a permissive judge might not only have a higher number of approvals, but even a higher number of denials, since he will see more marginal requests than a judge with a less permissive reputation. However, because of this endogeneity in the number of filings we cannot use the fraction of approved motions or the number of denied motions as an indicator for judge bias. Therefore, only the number of approved motions is a well defined indicator of judge bias in our set up.

The remainder of the paper is structured in the following way; section II discusses the filing process in Chapter 11, section III describes the data used in the current paper, section IV displays the analysis and results of the paper and finally section V concludes. 


\section{The Chapter 11 Process}

Chapter 11 bankruptcy protection is an attempt to allow firms which are in financial distress but otherwise are viable as going concerns to restructure their financials and their physical assets in order to keep operating. The aim of Chapter 11 is to prevent (unsecured) creditors from stripping the assets of the firm when it is socially optimal to allow the firm to continue, i.e. if the value of the firm as a going concern is higher than its liquidation value. Many practitioners therefore describe Chapter 11 as a fresh start for the firm. To avoid such a run in Chapter 11 an automatic stay is places on the assets, but the bankruptcy judge had the power to lift the stay. So the bankruptcy judge invariably has a lot of power within the process.

If the judge assigned to a case does not feel the firm meets this requirement, then the case is summarily converted to a Chapter 7 liquidation bankruptcy or dismissed altogether. Conversions and dismissals of this type are quite common and approximately half of all bankruptcy cases never reach the hearing stage.

Chapter 11 formally begins with the filing of a petition in district bankruptcy court. Although such petitions are almost always filed by the debtor, creditors meeting certain requirements may force a firm to file for involuntary bankruptcy. In addition an increasing number of cases are filed 'pre-packaged'. Essentially prepackaged cases are ones where the debtor files a petition with a reorganization plan that has already been negotiated by the firm, its creditors and if relevant, voted on by stockholders. For the purpose of this paper we will not include pre-packaged bankruptcy cases, since those cases do not allow for any action from the part of the judge.

After filing, Chapter 11 consists of three main parts. The first consists of the presentation of a plan of reorganization. Under Chapter 11 U.S. Code Section 1121, the debtor in possession has a 120 filing day 'exclusive period' during which they have the sole right to file a plan of reorganization. If the debtor has failed to file a plan during the first 120 filing days, the debtor can request to extend their exclusive period. If their request for an extension is denied, other parties may file their own plan for firm reorganization. Once a 
plan as been filed, creditors and equity holders vote to confirm the plan. A plan is considered confirmed when a majority consensus is reached as measured both in the number of creditors and fraction of the total debt owed. Finally once a plan has been confirmed, the process of reorganization begins with the implementation of the now approved plan of reorganization. Once completed to the court's satisfaction, the case is officially closed and the bankruptcy process is considered complete. Although on average this process takes approximately two years, it can take much longer depending on the complexity of each particular case.

Successful reorganization should allow a firm to operate as a financially viable entity. As such re-filing, even more than firm dissolution, can be seen as the ultimate failure of the bankruptcy process.

\section{Data Description}

The data for this paper stem from three main sources: (1) The Public Access to Court Electronic Records (PACER) electronic public access service, (2) Dun \& Bradstreet and (3) the National Establishment Time-Series (NETS) Database.

First, we obtain full case histories including the case docket from PACER. PACER is an internet based service which provides registered users with access to case and docket information for bankruptcy cases. ${ }^{5}$ Although the PACER service is run federally by the Administrative Office of the United States Courts, each district is responsible for maintaining its own separate website and database of case information. As such the content and quality of information provided varies by district.

Our PACER data universe consists of all Chapter 11 bankruptcies available during the summer of 2004 from the PACER system for the districts of Arizona, California (LA), California (ND), California (RS), California (SA), California (SV), Delaware, Georgia (North) and New Jersey. The dataset includes approximately 11,000 cases filed and completed between 1989 and 2003 for private and public companies. After dropping pre-packaged cases, Dun \& Bradstreet were able to match 6,266 cases to 6089 distinct firms in their data

\footnotetext{
${ }^{5}$ We thank the participating district courts for their generosity in waiving the fees for accessing their PACER entries.
} 
universe. $^{6}$

The PACER system allows authorized users to download the complete docket information for cases filed in Bankruptcy court. To deal with the enormous size of the sample, we utilized a computer algorithm to parse through the docket information and code the individual motions and decisions that a judge ruled on. We concentrate on 18 rulings that from our reading of the legal literature on the Chapter 11 process are considered most important. ${ }^{7}$ For that purpose we construct a large number of indicator variables which take up the values 0 and 1 depending on whether a judge makes that type of ruling in a case. The most important decisions taken by bankruptcy judges are orders to (1) dismiss a case, (2) convert a case from Chapter 11 to Chapter 7, (3) grant an extension of the exclusivity period, (4) grant a lift of the automatic stay, (5) allow the debtor to use cash collateral and (6) allow the sale of assets. Table 5 shows that cash collateral requests are granted in only $1.4 \%$ of the case and denied in over $32 \%$; conversion to chapter 7 happens in about $2 \%$ of the cases and denied in less than 1\%; dismissal is granted in only $3 \%$ of the cases and denied in about $74 \%$; lifting a stay is granted in $8 \%$ of the cases and denied in $32 \%$; and finally the granting and denying a sale both appear with a probability below $1 \%$.

For each case in our sample, we then examined the entire docket coding by hand to verify that the extract filings correspond to the actual rulings. We were especially careful to check that the algorithm did not suffer from type II errors and excluded valid motions. However, since a majority of the district courts only switched to fully electronic filing during the year 1997. To avoid any sample selection biases from differential adoption of PACER we replicated all our tests using only the sub-sample starting in 1998 and our results are unchanged. We include Chapter 11 filings of private as well as public companies, with the majority being private firms. The frequency of the filing events by year and district are presented in Table 4.

We also obtain information on the re-filing rate (and date) of cases that had previously

\footnotetext{
${ }^{6}$ Dun \& Bradstreet were able to match 8,000 cases to firms, but we chose to drop those matches Dun \& Bradstreet did not designate as "high confidence" matches.

${ }^{7}$ See for example Baird (2002).
} 
gone through Chapter 11 if they happen within our sample period. About 2.9\% of the cases in our sample land in bankruptcy court again. On average the firms that refile take about 1.1 years before re-enter bankruptcy.

Using the data from Dun \& Bradstreet, we were able to obtain some characteristics of the firms in our bankruptcy sample. The D\&B data contains information on the sales, number of employees and some financial information for nearly 100 million firms. The benefit of $\mathrm{D} \& \mathrm{~B}$ is that it also includes information on private firms if these firms ever had a credit record. This will almost by definition be the case for the majority of firms that land in Chapter 11. By using a combination of firm name, address and Tax ID numbers the cases were matched to firm financial records by Dun \& Bradstreet. Fourth quarter credit ratings were available for 1317 of these firms for the years 1997-2003. Summary statistics for the cases in our sample are presented in Table 2.

The average firm in the $\mathrm{D} \& \mathrm{~B}$ sample has sales of $\$ 1.7$ million, ranging from less than one thousand dollars in sales to over $\$ 50$ million in sales. Employment range from 0 to 2,500 employees with an average of 22 employees per firm. As we can see from Panel B of Table 2 the average firm in the NETS sub-sample tends to be larger than those in the entire sample. NETS matched firms have average sales of $\$ 2.7$ million, ranging from 15 thousand dollars to over $\$ 150$ million. Similarly, NETS firms have both a higher average and variance in the number of employees. In comparing the two data sets we find that the main observable differences between the D\&B universe and the NETS data is that NETS data have significantly higher sales, only slightly higher employment and significantly higher credit ratings and incorporation rates, all of which might be driven by the difference in average firm size.

\section{Random Assignment}

As discussed above our identification strategy will rely crucially on the assumption that in Chapter 11 cases are randomly matched to judges. If the assumption of random assignment was violated, judge specific effects could not be meaningfully estimated. Instead the ob- 
served ruling of a judge might reflect the demands of the case and not the judge's judicial philosophy or biases. For example, imagine one judge who is specialized in difficult cases and another judge in simpler bankruptcy cases. Then the judge with the more difficult cases might appear to rule more often to allow an extension of the automatic stay which could be misinterpreted as having a pro-debtor bias. However, under this scenario a large fixed effect for the judge with the difficult cases could rather be driven by the fact that difficult cases more often require the extension of the automatic stay, since the parties in the case cannot agree on a compromise.

In theory, random assignment of cases to judges seems a very reasonable assumption. Procedurally judges within a district randomly draw new cases from the pool of pending applications. 8 Therefore although firm characteristics might depend on the district in which the firm operates, within districts, firms and judges should be randomly paired. ${ }^{9}$ If the set of cases assigned to each judge is comparable, differences in rulings can then be interpreted as the result of judge specific effects.

By law a firm is only allowed to file for bankruptcy in districts in which it operate. Since most small firms have operations in only one district, they do not have a choice which district to file in. This is different for large firms that have operations in several states and district and thus might be able to engage in so called forum shopping. Therefore throughout the paper we make sure all our results hold when we exclude when we exclude the top deciles and quartile of firms by sales. ${ }^{10}$ Within a given district the procedures of most bankruptcy courts prescribe that cases are randomly assigned to available judges. Moreover, when we

\footnotetext{
${ }^{8}$ An exception to this method occurs when two or more cases are related. Although the assignment of related cases is not random, as long as the initial case is randomly assigned, effective randomization should still occur. New Jersey explicitly states their rule for case assignment in D.N.J. LBR 1073-1(d): 'If the petition commencing a case states in writing that the case is related to another case which has been or is being filed in the same vicinage, the clerk shall assign the case to the judge to whom the lowest numbered related case has been assigned. All other case assignments shall be made by the random draw method used by the Court.'

${ }^{9}$ See Eisenhard and LoPucki (1999) for a discussion of random assignment in Chapter 11.

${ }^{10}$ Excluding the top decide or quartile of firms by sales have no significant effect on any of our findings. This should not be seen as evidence either for or against the existence of forum shopping. Rather it merely suggests that forum shopping by the multi-State firms simply does not lead to a significant change in the overall composition of bankruptcies filed in any given district.
} 
talked to the clerks of several of the participating bankruptcy courts they verified that this is the procedure they follow.

One might be worried, however, that even if the courts use random assignment to decide which judge precede a given case, the timing of filing of cases is not. For example, knowledgeable bankruptcy lawyers might know when a given judge has a light case load and thus file at a strategic time to obtain a higher chance to be assigned to this judge. For that purpose we test the assumption of random assignment more directly. We run a regression of different characteristics of the firms that end up in Chapter 11 on the set of judge fixed effects. The observable characteristics that are available to us are the annual sales of the firm, the number of employees and the credit rating at the end of the year in which the firm filed for bankruptcy. We also need to control for an interaction of district and year fixed effects. This control is important if the case load and composition of cases changes over time in a district. Therefore a control for the changes in the composition of cases that come to the court in a given period is required.

Specifically for each type of filing, we estimate the following regression:

$$
y_{i}=\alpha_{d t}+\gamma_{i}+\beta X_{i t}+\lambda_{j u d g e}+\epsilon_{i}
$$

where $y_{i}$ is a dummy for whether a particular order was issued, $\alpha_{d t}$ are district varying year fixed effects, $\gamma_{i}$ is a dummy for whether the case was filed voluntarily, $X_{i t}$ represents a vector of district varying firm level controls and $\epsilon_{i}$ is an error term. The remaining term $\lambda_{\text {judge }}$ is the fixed effect of each judge. This fixed effect can be seen as the relative rate at which each judge grants or denies a particular motion. Because each judge serves in only one district ${ }^{11}$, district effects are not included as they would be perfectly collinear with judge fixed effects. Therefore, whenever we need to directly compare individual fixed effects across our different districts, the fixed effect coefficients are demeaned at the district level.

Panel A of Table 6 shows the results from an F-test on the set of judge fixed effects from

\footnotetext{
${ }^{11}$ One judge did have a small fraction of her cases in a second district. Those cases were dropped from our sample.
} 
a regression of the logarithm of sales on the specification described above. We see that the Fstatistic is small and rejects the hypothesis that the judge fixed effects are jointly significant. As seen in Table 6, there appears to be no evidence that judge fixed effects jointly explain average sales. We then repeat these tests for the number of employees. Again we find that the F-test on the joint significance of the judge fixed effects is not significant. These results also hold true if we estimate judge fixed effects for each individual district separately. We also re-estimate the judge fixed effects for different subsets of the data, windsorizing either at the $5 \%, 10 \%$ or $20 \%$ hurdle and get quantitatively similar results.

In Panel B of Table 6 we replicate the results for the smaller sample of NETS data. The results again are qualitatively unchanged; again we do not find evidence that judge fixed effects are jointly significant in explaining how cases are allocated to judges. These findings hold if we leave out each individual district, remove all judges with fewer than 10 , 15 or 20 cases, or drop the (in)voluntary cases. We also find that these results are robust to dropping all cases that were filed prior to 1998. As discussed above, the number of courts that adopted the PACER system was very small prior to 1997.

Overall these results suggest that there is random assignment of Chapter 11 cases to judges and thus case allocation is independent of the firms' observable characteristics, such

as firm size, measured as sales and employees at the time of filing. Given the stated allocation rules of bankruptcy courts, these findings reassure us that firms are not matched to judges in some measurably biased way. This is a very powerful result since it will allow us to estimate judge fixed effects on the decisions they take and interpret them as a reflection of the judges specific leanings or biases and not an outcome of the type of cases that are allocated to the judge.

\section{$5 \quad$ Judge Specific Differences}

Since we are able to verify that cases are randomly assigned to judges, we can now estimate whether there are judge specific fixed effects in the way judges rule in Chapter 11 . To test whether judges vary systematically in their approach to Chapter 11 rulings, we repeat 
an estimation strategy parallel to the one used above. As dependent variables we use the different motions a judge approves or dismisses during the Chapter 11 process. For example, we regress an indicator for whether a judge grants a creditor's motion for relief from the automatic stay on the set of judge dummies and the interaction of year and district fixed effects. We then conduct an F-test for whether the judge fixed effects are jointly significant. We repeat this estimation procedure separately for all judge decisions.

The results from this exercise are markedly different from the results in the previous section. In fact, almost all the F-test on the different judge decisions are jointly significant. Table 5 shows that F-tests on most of the judge decision variables are large and significant. Specifically we find large and very significant F-tests for the granting and denying of motions requesting the use of cash collateral, granting and denying motions to convert the case to Chapter 7, granting and denying of motions for dismissals and granting and denying motions for relief from the automatic stay. According to the bankruptcy literature these are very important decisions in Chapter 11, see for example Gertner and Scharfstein (1991). In contrast, we find that the F-tests tend not to be significant for those rulings that are rarely utilized, such as granting a sale of assets or an extension to the exclusivity period. Both of these rulings occur in less than $0.5 \%$ of the bankruptcy cases, which suggests that the incidence rate of these motions if too low to find significant results.

These results hold if we include firm level controls in the regression such as logarithm of sales, number of employees or industry fixed effects. This is not surprising since we had previously shown that judges are randomly assigned to cases. Moreover, we again repeat the regressions for the smaller sample of NETS data. The results are very similar to the findings in the full data set but slightly noisier. This is not surprising since the power of the test is much lower, as we are loosing more than $50 \%$ of the observation when using the NETS dataset.

Overall, these results suggest that there is large and significant heterogeneity in the propensity of judges to grant a given motion. This finding demonstrates that depending on which judge is assigned to a given case the rulings on the case varies dramatically. In the 
appendix we report the estimated fixed effects for the individual judges. We see that in the cases where the F-test is highly significant, even the t-tests on the individual fixed effects are significant for most of the fixed effects. So a judge who has a particularly low estimated fixed effect has a lower than average propensity to grant a particular motion. And a judge who is at the higher end of the fixed effect distribution has also a higher propensity to grant the motion. Put simply, judges play a central role in how bankruptcy law is applied to an individual case.

Finally, for the interpretation of our results it is important to note that while we show that cases are randomly assigned to judges in Chapter 11, the different parties in bankruptcy, especially the lawyers who represent the creditors or the management, might know the reputation of the judge they were assigned to. Given their expectation of succeeding with a specific motion, the different parties in bankruptcy might endogenously choose whether or not to file a motion in the first place. Take the case of a very strict judge who is known to only very rarely allow an extension of exclusivity or to lift an automatic stay. In that case the lawyers of the different parties in bankruptcy might not even try to file a certain motion, since they expect rejection and vice versa in the case of a judge who is considered more permissive. Therefore, a permissive judge might not only have a higher number of approvals, but also a higher number of denials, since she will see more marginal requests than a judge with a less permissive reputation.

Because of this endogeneity in the number of filings we cannot use the fraction of approved motions or the number of denied motions as an indicator for judge bias. Therefore,

only the number of approved motions is a well defined indicator of judge bias in our set up. Therefore, going forward we will only use the fixed effects on the number of granted motions as an indicator for a judge's bias.

\section{Pro-debtor and pro-creditor index}

So far we have shown that there is significant heterogeneity in how judges rule on specific provisions in Chapter 11. We now want to understand whether there are consistent patterns 
in the rulings of judges across different petitions. So for example, does a judge who has a strong positive fixed effect on granting extensions of the exclusivity period also displays pro-debtor tendencies on other provisions, e.g. allows the use of cash collateral or never lifts the automatic stay. In contrast, one could imagine that judges have personal judicial philosophies in how they apply certain rulings but no consistent bias.

To test the correlation structure between different judge fixed effects we conduct a principal component analysis. As discussed above we only include fixed effects on the petitions that are granted by a judge but not those that were denied. We include the most important rulings in the Chapter 11 process that can be clearly characterized as prodebtor or pro-creditor. Under the rather reasonable assumption that no party would request something harmful to itself, we classify motions that are mostly requested by creditors as pro-creditor and those submitted by debtors as pro-debtor. We include eight types of motions that are filed exclusively by either the debtor or creditors. The debtor filed motions are request for (D1) the use of cash collateral, (D2) extensions to the exclusivity period and (D3) the sale of assets, and (D4) objections to the plan of reorganization by creditors. The creditor filed motions are requests for (C1) case dismissal, $(\mathrm{C} 2)$ conversion of case to Chapter 7, (C3) lifting the automatic stay, and (C4) objections to the reorganization plan by debtors.

We find a very consistent structure in our principal component analysis. The first principal component is by far the most important one and explains about $40 \%$ of the variation across judge fixed effects. This component loads very positively on the motions that are pro-debtor (D1 to D4) and also loads very negatively on the motions that are pro-creditor ( $\mathrm{C} 1$ to $\mathrm{C} 4)$. These findings suggest that judges are very consistent in how they rule on motions, i.e. across the different motions a given judge shows either a systematic bias towards the debtors or the creditors.

This finding also suggests that we can combine the judge's bias (the size of the judge fixed effects) across different motions to create a proxy for his or her overall tendency to rule in favor of the debtor or creditor. To capture whether or not a judge displays a pro-debtor 
bias (leniency) we create an index using a combination of the estimated judge fixed effects. We combine the judges fixed effects on the six motions and two objections which we can classify as pro-debtor or creditor into an index. For that purpose we assign a dummy equal one to any judge who scores above the median on one dimension of fixed effects and a minus one for any judge who scores below the median. We repeat this classification for all the eight events. Finally we sum the dummies on the pro-debtor motions and subtract those on the pro-creditor motions. This index ranges from eight for the most pro-debtor judge to minus eight for the most pro-creditor judges. An important intrinsic assumption this index makes is that each of our eight motions are equivalent signals of a judge's bias. That is the bias a judge shows in granting case dismissals has the same weight as granting extensions of the exclusivity period. Although this is likely an oversimplification, it has the advantage of not relying on exogenous assumptions about a motions relative signaling value.

We also include a second set of indicators to characterize the judges' biases in Chapter 11. It may be the case that motioned filed by one side (debtors or creditors) have more of an effect than the other. For that reason we also create a second set of dummies that counts the pro-debtor motions separately from the pro-creditor motions. In a parallel proceedure to the one described above, we create an indicator (PD) that sums up the judge's fixed effects on the motions that favor debtors (D1-D4). We the repeat the process to create a separate indicator (PC) for the judges fixed effects on the motions that favor creditors (C1-C4). Both these variables run from +4 to -4 .

\subsection{Effect of Pro-Debtor or Pro-Creditor Judges}

In Table 7 we report the results of a regression of different outcome variables on the prodebtor/creditor index controlling for district and year effects. We see that pro-debtor judges increase a firm's chances of re-filing by $1.7 \%$. Since the re-filing base rate in our sample is only $3.0 \%$, this represents a substantial increase in the propensity to re-file. In column (2) we then replicate the regression using the likelihood of shutdown as the dependent variable. Again we find that pro-debtor judges show a significantly higher shutdown probability $(5.6 \%)$ than pro-creditor judges. But since the probability of shutdown for firms in our 
sample is $28.5 \%$, this represents a smaller relative effect than the one we find for re-filing rates. These outcomes are very surprising since one might have expected that pro-debtor judges would have a larger tendency to maintain firms as going concerns. Column (2) replicates these results using the smaller sample of the NETS data. We see that the findings are qualitatively very similar but less significant, since we have reduced power in this much smaller dataset.

In Panel B of Table 7 we repeat this estimation but use sales growth, employment growth and change in credit rating post bankruptcy as the dependent variables. Unfortunately, with the exception of the $\mathrm{D} \& \mathrm{~B}$ credit rating, we only have a panel data for these dimensions for the reduced sample based on NETS data. ${ }^{12}$ Row (1) of Panel B of Table 7 are based on the D\&B credit rating for the full sample of cases, but unfortunately we only have a limited panel for credit rating in our current D\&B data set. Because the credit ratings provided by Dun \% Bradstreet are non-linear (credit ratings are integers from 0 to 5), a dummy was created to determine whether a firm's credit rating increased in relation to a reference year. The results show a rather striking pattern where the effect of pro-debtor judges is negative and increasing over time, with significance at four and five years out.

We then replicate the panel regressions in the smaller NETS data set where we can observe changes in sales, employment growth and PAYDEX scores. Using the NETS data set, we find that there is a decrease in sales growth for the pro-debtor judges for all five years after the bankruptcy filing, but the results are only significant in the fourth and fifth year after the initial filing. Similarly we find a negative coefficient on employment growth for each of the five years post-bankruptcy filing, but the results are not significant. Finally we find negative effects of the pro-debtor indicator on the firm's credit rating (PAYDEX min and max are the equivalent of D\&B credit scores in the NETS data) but the estimated effects are not significant throughout, we believe that this is most likely because of the reduced data set.

Table 8 repeats this analysis, but with the pro-debtor dummy broken into a pro-debtor

\footnotetext{
${ }^{12}$ We are currently trying to get a larger data set of these observable characteristics.
} 
(D1-D4) and pro-creditor (C1-C4) component as discussed above. The results largely mirror those found in Table 7. We again find that pro-debtor judges have higher re-filing rates and a higher fractions of shut downs. Interestingly, these results seem to be driven by the judges' decisions on motions that are pro-debtor, while the judges' scoring on the procreditor index are not significant for these outcomes. This suggests that the judge's ruling on the pro-debtor motions is more important for these outcomes than the pro-creditor motions. One additional result in row (2) of Table 8 is that a pro-creditor bias leads to an eighteen day reduction in case length. Here the judges' score on the pro-creditor decisions is more significant than the pro-debtor.

These results are very surprising given the prior discussion of the US Chapter 11 process. We defined pro-debtor judges as those that are heavily skewed towards favoring debtors when ruling on motions that can either hurt or help debtors. These motions include for example, extending the exclusivity period, or allowing the firm to use cash collateral to finance ongoing operations. In contrast judges who we classify as pro-creditor allow many more motions that are aimed at protecting the assets of the creditors such as lifting the automatic stay, in the reorganization process. Therefore, we would expect that pro-creditor judges who give more power to creditors, should lead to less continuation (even efficient continuations), since creditors only care for the protection of their assets. In contrast, equity benefits most when the firm survives as a going concern and thus pro-debtor judges should show a higher rate of continuation. However, we actually find the opposite, with prodebtor judges producing higher firm shut down rates than pro-creditor judges. Moreover, pro-creditor judges had lower re-filing rates and show better outcomes for those firms that do survive post-chapter 11. These findings are very surprising. First they suggest that pro-creditor judges are actually more beneficial for the continuation value of the firm than pro-debtor judges. This outcome is not driven by the fact that pro-creditor judges just have a high hurdle rate in whom they let through Chapter 11 and which firms they shut down. This raises a fundamental question why equity holders are not able to protect their interest as a going concern as effectively when the firm is allocated to a pro-debtor judge. One 
suggestion is that equity is not represented adequately by management in the bankruptcy process.

\subsection{Differential Effects for Larger Firms and Corporations}

To analyze the impact of governance structures on the restructuring process in Chapter 11 we would ideally like to obtain information on the management team of the firms, whether a firm is owner managed or has separation of ownership and management, or other indicators of agency problems within the firm. We would also like to know the composition of secured and unsecured lenders. Unfortunately we currently do not have access to this information. If the counter-intuitive results discussed before are driven by governance problems between owners and managers, we would expect that pro-debtor judges have a more negative effect for larger and incorporated firms, since those are more likely to have separation of management and control. In contrast if the results are due to the fact that pro-debtor judges might make it easier for equity to divert resources from the bankruptcy estate, then the effect should be larger for smaller, owner operated firms. ${ }^{13}$ Therefore, we use the size of a firms and its incorporation status as a proxy for the severity of the agency problem within the firm. Our assumption is that smaller firms and those that are not incorporated are more likely to be owner operated and have fewer governance problems.

To estimate the differential effect of a pro-debtor judge on larger or incorporated firms we repeat regressions structure in Table 8 but include interaction terms between (1) the pro-debtor index and a dummy for whether a firm is incorporated or not, (2) the pro-debtor dummy and the logarithm of sales of the firm in the year prior to bankruptcy filing. Column (1) in Table 9 shows the results from a regression of the out of business indicator on $\log$ sales interacted with the pro-debtor dummy is positive but just marginally insignificant (the t-statistic is about 15\%). The same pattern holds in column (2) which reports the interaction between the pro-debtor indicator and the incorporation dummy. This suggests

\footnotetext{
${ }^{13}$ We are in the process of obtaining information on the capital structure and asset base of the firms at the moment of bankruptcy filing from their Chapter 11 filing documents.
} 
that likelihood of re-filing increases even more for larger, incorporated firms when they are allocated to a pro-debtor judge.

In columns (3) and (4) we repeat the same regressions using the log change in sales four years out as the dependent variable. The sign on the interaction terms is negative but not significant. Columns (5) and (6) [(7) and (8)] replicate the regressions using PAYDEX min (PAYDEX max) four years out as the dependent variable, respectively. These are the credit scoring variables available from NETS. We find that the coefficient on the interaction terms is negative and significant at the $5 \%$ level in all the regressions. Overall these results suggest that a pro-debtor judge has worse effects on firms' continuation values in larger and incorporated firms. These findings are consistent with the interpretation that pro-debtor judges create an environment that exacerbates the governance problems between managers and shareholders. The results do not support the interpretation that owner-managers (of small companies) transfer value out of the firm during the Chapter 11 process. ${ }^{14}$

\section{Outcomes of Individual Decisions}

Finally want to explore whether specific rulings in Chapter 11 have an impact on the outcome of a case. This analysis aims to understand whether there are specific dimensions of the pro-debtor or pro-creditor index that are particular important for a given outcome. We do not however want to claim that this analysis proves that only those dimensions matter since there might be other, potentially even procedural dimensions, through which a judges can affect the bankruptcy process.

We therefore take an alternate approach for our analysis. We use the estimated judge fixed effects as an instrument for each specific ruling. This allows us identify the impact of a specific ruling based on the judges pre-disposition to rule in favor or against a certain motion based not on the characteristics of the case but on the an individual judge's predispositions or biases. As discussed above we cannot simply look at the correlation between judge rulings and outcomes in the cross section, since judge decisions are likely related to the unobservable

\footnotetext{
${ }^{14}$ Of course we cannot in our data rule out that owner-managed firms might have already transferred assets out of the firm prior to filing for Chapter 11.
} 
characteristics of the case. Since we cannot obtain consistent estimates via OLS, we use an instrumental variable approach with the judge fixed effects as our instruments.

Specifically we run:

$$
y_{i}=\alpha_{d t}+\gamma_{i}+\beta X_{i t}+\Lambda A_{i j}+\eta_{j}+\epsilon_{i}
$$

where $y_{i}$ is the outcome of interest and $\alpha_{d t}, \gamma_{i}$ and $\beta X_{i t}$ are defined as before. An additional error term $\eta_{j}$ is included to reflect the potential clustering of error at the judge level due to our instrument. $A_{i j}$ represents the vector of rulings in case $i$ instrumented by the assigned judge's fixed effects (e.g. his or her relative propensity for each specific rulings). Since a judge propensity for a given action is almost entirely independent of any one case and highly correlated with the action itself, they provide almost ideal instruments for our analysis. We restrict our set of independent variables to the rulings that were significant in the first stage.

As discussed above we can only meaningfully include the granting of a motion but not a denial, since denials are a combination of the judge's likelihood to approve a motion and the endogenous response by the parties in bankruptcy to file a motion. The two forces move in opposite directions and could therefore bias the results in an indeterminate direction.

Table 10 reports our results for bankruptcy re-filing rates as the outcome variable. We construct an index variable equal to one if a firm re-files for bankruptcy within the next three years after the first filing. ${ }^{15}$ In column (1) of Table 10 we see that in the simple OLS regression without using our instrumentation strategy, none of the motions are significant. However, once we instrument the different motions with the judge fixed effect we see in column (2) that a number of different motions have a significant relationship to refiling. Especially significant are extensions of the exclusivity period and permitting the debtor to us cash collateral.

\footnotetext{
${ }^{15}$ We replicated this regression for different windows of years after the bankruptcy filings, and the results are virtually unchanged.
} 
We also replicated the results for the outcome variables in the smaller sample of NETS data. While the results tend to have the expected signs on the judge decisions, the sample size is too small to find any significant results.

\section{Conclusion}

Our study suggests that there is large heterogeneity in the ruling of judges in Chapter 11. Independent of the characteristics of the case, some judges seem to have a differential propensity to rule in favor of creditors or debtors. When we use these judge specific differences to proxy for the pro-debtor (pro-creditor) friendliness of a court, we find that judges who score higher on our pro-debtor index tend to have lower continuation, higher re-filing rates and also show a larger deterioration of credit scores in the 3, 4, and 5 years after coming out of Chapter 11. These results are quite counter-intuitive since at the margin equity holders who have limited liability should be more concerned about continuation.

We conjecture that a failure of governance within firms could be at the core of these findings. If the interest of equity is not adequately represented in the bankruptcy process, more specifically, if management is able to extract private financial benefits during the restructuring process, it might come at the expense of the long term continuation value for equity holders. An alternative explanation would be that a restructuring process that is tilted towards debtors allows equity itself to extract financial resources from the firm instead of keeping assets tied up in firm. For example, owner-managers who are in control of dayto-day management of the firm might be able to take the most important assets out of the firm ad set up a similar firm in parallel. If this extraction technology for equity is not too inefficient, continuation might be less attractive than a prolonged bankruptcy process and potential shut down, since in continuation the owners would have to share future income with other claim holders.

Ignoring these important implications firm level governance plays in the restructuring of distressed firms might result in policy implications that are not in the interest of the parties they are supposed to protect. Going forward much more research is needed to understand 
how distress resolution interacts with the governance structure of firms that enter distress. 


\section{References}

Administrative Office of the U.S. Courts, Press Release, December 2004.

Aghion, Philippe, Oliver Hart and John Moore, 1992, "The Economics of Bankruptcy Reform," Journal of Law, Economics and Organization, vol. 8(3), p 523-546.

Anderson, J., Kling, R. and Stith, K., 2001, "Measuring Inter-Judge Sentencing Disparity Before and After the Federal Sentencing Guidellines," Journal of Law and Economics, Vol. 42, p. 271-307.

Baird, Douglas and Edward Morrison, 2001, "Bankruptcy Decision Making," Journal of Law, Economics and Organizations, Vol. 17, p. 356-371.

Baird, Douglas and Edward Morrison, 2005, "Serial Entrepreneurs and Small Business Bankruptcies," Working Paper Columbia law School.

Baird D., and Rasmussen, P., 2002, "The End of Bankruptcy," Stanford Law Review, p. 751.

Baird D., and Rasmussen, P., 2003, "Chapter 11 at Twilight," Stanford Law Review, p. 101-129.

Berglof, E and E.L. von Thadden, 1994, "Short-Term Versus Long-Term Intrests: Capital Structure with Multiple Investors," Quarterly Journal of Economics, Vol. 109, p. 1055-1084.

Bergman, Y. Z., and Callen, J. L., 1991, "Opportunistic Underinvestment in Debt Renegotiation and Capital Structure," Journal of Financial Economics, Vol. 29, p. 137-171.

Betker, B., 1995, "Management's Incentive, Equity Bargaining Power and Deviation from Absolute Priority in Chapter 11 Bankruptcies," Journal of Business, Vol. 68, p. 161184.

Bolton, P. and D. Scharfstein, 1996, "Optimal Debt Structure with Multiple Creditors," Journal of Political Economy, Vol. 104, p. 1-25.

Bradley, M., and Rosenzweig, M., 1992, "The Untenable Case for Chapter 11," Yale Law Journal, 101, p. 10431095.

Bris, A., Welch, I. and Zhu, N., 2006, "The Costs of Bankruptcy," Journal of Finance, Vol. 61(3), p. 1253-1303.

Dewatripoint, M and J. Tirole, 1994, "A Theory of Debt and Equity: Diversity of Securities and Manager-Shareholder Congruence," Quarterly Journal of Economics, Vol. 109, p. 1027-1054.

Eisenberg, Theodore and Lynn LoPucki, 1999, "Shopping for Judges: An empirical Analysis of Venue Choice in Large Chapter 11 Reorganizations," Cornell Law Review, Vol. 48. 
Gertner, Robert and David Scharfstein, 1991, "A Theory of Workouts and the Effects of Reorganization Law," Journal of Finance, Vol. 46, p. 1189-1221.

Gilson, S. C., and M. R. Vetsuypens, 1993, "CEO Compensation in Financially Distressed Firms: An Empirical Analysis," Journal of Finance, Vol. 43, p. 425-458.

Hart, Oliver, 2000, "Different Approaches to Bankruptcy," Harvard Institute of Economic Research Working paper.

Hotchkiss, E., 1995, "Postbankruptcy Performance and Management Turnover," Journal of Finance, Vol. 50, p. 3-21.

Jensen, Michael and William H. Meckling, 1976, "A Theory of the Firm: Governance, Residual Claims and Organizational Forms," Journal of Financial Economics, Vol. 3(4), p. 305-360.

Kling, J., 2006, "Incarceration Length, Employment, and Earnings," American Economic Review, forthcoming 2006.

LoPucki, L., and W. Whitford, 1993, "Patterns in the Bankruptcy Reorganization of Large, Publically Held Companies," Cornell Law Review, Vol. 78, p. 597-618.

LoPucki, L., and Doherty, J., 2004, "The Determinants of Professional Fees in Large Bankruptcy Reorganization Cases," Journal of Empirical Legal Studies, .

Myers, Stewart C., 1977, "Determinants of Corporate Borrowing," Journal of Financial Economics, Vol. 5, p. 147-175.

Ravid, S., and Sundgren, S., 1998, "The Comparative Efficiency of Small-Firm Bankruptcies: A Study of the US and Finnish Bankruptcy Codes," Financial Management, Vol. $27(4)$.

Rasmussen, R., and Thomas, R., 2000, "Timing Matters: Promoting Forum Shopping by Insolvent Corporations," NWU Law Review, Vol. 94, p. 1357-1391.

Skeel, David A., 2003, "Creditors' Ball: The 'New' New Corporate Governance in Chapter 11," University of Pennsylvania Law Review, Vol. 152(2), p. 917-951.

Smith, C., and Stromberg, P., 2005, "Maximizing the value of distressed assets: Bankruptcy law and the efficient reorganization of firms," Working Paper, available at http://www.sifr.org/PDFs/smithstromberg(wb2005).pdf.

Stromberg, P. and Thorburn, K., 1996, "An Empirical investigation of Swedish Corporations in Liquidation Bankruptcy," EFI research report, Stockholm School of Economics.

Thorburn, K., 2000, "Bankruptcy Auctions: Costs, Debt Recovery, and Firm Survival," Journal of Financial Economics, 58, p. 337-368.

United States Bankruptcy Court: Central District of California, Judicial Variance Survey, March 2001. 
United States Bankruptcy Court: District of New Jersey, Local Bankruptcy Rules, August 2005 .

United States Bankruptcy Court: uscourts.gov, Bankruptcy Basics, 2006.

Warren, E., 1992, "The Untenable Case for Repeal of Chapter 11," Yale Law Journal, 102, p. $437-479$.

Weiss, Lawrence and Karen Wruck, 1998, "Information Problems, conflicts of interest and asset stripping Chapter 11's failure in the case of Eastern Airlines," Journal of Financial Economics, Vol. 48, p. 55-97. 
Table I

Variable Descriptions

\begin{tabular}{|c|c|c|}
\hline Name & Source & Description \\
\hline Case Duration & $P A C E R$ & The number of days between the first and last docket filing. \\
\hline Corporation & Dun E Bradstreet & A dummy for whether a firm is a formal corporation. \\
\hline Credit Rating & Dun E Bradstreet & D \& B's proprietary composite measure of credit worthiness. \\
\hline Employees & Dun $\&$ Bradstreet & Total number of employees for the year before bankruptcy filing. \\
\hline Out of Business & NETS & $\begin{array}{l}\text { A dummy for whether a firm disappears from the D\&B universe } \\
\text { within three years of filing for Chapter } 11 \text {. }\end{array}$ \\
\hline PAYDEX & NETS & $\begin{array}{l}\text { PAYDEX is a dollar-weighted } 1-100 \text { numerical score that } \\
\text { indicates a company's payment performance as reported to D\&B. } \\
\text { Higher scores are better. }\end{array}$ \\
\hline PAYDEX min & NETS & Minimun PAYDEX score during a calendar year. \\
\hline PAYDEX max & NETS & Maximum PAYDEX score during a calendar year. \\
\hline Refile & $P A C E R$ & $\begin{array}{l}\text { Whether a firm refiles for bankruptcy in the same district } \\
\text { within three years. }\end{array}$ \\
\hline Sales & Dun $\&$ Bradstreet & Total sales for the year before bankruptcy filing. \\
\hline Voluntary & PACER & A dummy for whether a firm voluntarily filed for Chapter 11 . \\
\hline
\end{tabular}


Table II

Descriptive Statistics ${ }^{a}$

\begin{tabular}{|c|c|c|c|c|c|}
\hline \multirow[t]{2}{*}{ Panel $A$} & \multicolumn{5}{|c|}{ Firm level data: Dun \& Bradstreet } \\
\hline & Mean & Std. Dev. & Min Val. & Max Val. & Count \\
\hline Sales & 1.7 million & 510,000 & 750 & 55 million & 5465 \\
\hline Employees & 21.75 & 103.81 & 0 & 2,500 & 5465 \\
\hline Refile Rate & 0.03 & 0.17 & 0 & 1 & 5465 \\
\hline Corporation & 0.62 & 0.49 & 0 & 1 & 5465 \\
\hline Voluntary & 0.97 & 0.16 & 0 & 1 & 5465 \\
\hline Credit Rating & 0.41 & 1.29 & 0 & 5 & 1060 \\
\hline \multirow[t]{2}{*}{ Panel B } & \multicolumn{5}{|c|}{ Firm level data: NETS } \\
\hline & Mean & Std. Dev. & Min Val. & Max Val. & Count \\
\hline Sales & 2.7 million & 7.0 million & 15,000 & 150 million & 1813 \\
\hline Employees & 23.86 & 54.69 & 1 & 1,500 & 1817 \\
\hline Refile Rate & 0.04 & 0.19 & 0 & 1 & 1813 \\
\hline Corporation & 0.77 & 0.42 & 0 & 1 & 1813 \\
\hline Voluntary & 0.98 & 0.13 & 0 & 1 & 1813 \\
\hline Credit Rating & 0.71 & 1.64 & 0 & 5 & 464 \\
\hline
\end{tabular}

${ }^{a}$ Notes:

1. The sample in Panel A is the firm-level panel dataset constructed from the merged PACER and Dun \& Bradstreet datasets (see text for more details.) The sample period is 1998-2004.

2. The sample in Panel B contains only those firms that we were able to match to records in the NETS database. 


\section{Table III}

Descriptive Statistics by Judge Bias ${ }^{a}$

\begin{tabular}{|c|c|c|c|c|}
\hline \multirow[t]{3}{*}{ Panel $A$} & \multicolumn{4}{|c|}{ Firm level data } \\
\hline & \multicolumn{2}{|c|}{ Pro-Debtor Judges } & \multicolumn{2}{|c|}{ Pro-Creditor Judges } \\
\hline & Mean & Std. Dev. & Mean & Std. Dev. \\
\hline $\log$ (Sales) & 12.99 & 1.73 & 12.99 & 1.94 \\
\hline $\log ($ Employees $)$ & 1.72 & 1.60 & 1.72 & 1.77 \\
\hline Refile Rate & 0.33 & 0.17 & 0.23 & 0.15 \\
\hline Corporation & 0.67 & 0.47 & 0.65 & 0.48 \\
\hline Voluntary & 0.98 & 0.15 & 0.98 & 0.16 \\
\hline Credit Rating & 0.29 & 1.10 & 0.22 & 0.97 \\
\hline \multirow[t]{2}{*}{ Panel B } & \multicolumn{4}{|c|}{ Industry Breakdown by District } \\
\hline & Pro- $D$ & btor Judges & Pro- $C r$ & editor Judges \\
\hline $\mathrm{SIC} 1^{*}$ & \multicolumn{2}{|c|}{$7.04 \%$} & \multicolumn{2}{|r|}{$7.70 \%$} \\
\hline $\mathrm{SIC} 2^{*}$ & \multicolumn{2}{|c|}{$4.61 \%$} & \multicolumn{2}{|r|}{$3.50 \%$} \\
\hline $\mathrm{SIC} 3^{*}$ & \multicolumn{2}{|c|}{$4.95 \%$} & \multicolumn{2}{|r|}{$3.50 \%$} \\
\hline $\mathrm{SIC} 4^{*}$ & \multicolumn{2}{|c|}{$4.56 \%$} & \multicolumn{2}{|r|}{$4.55 \%$} \\
\hline $\mathrm{SIC} 5^{*}$ & \multicolumn{2}{|c|}{$20.15 \%$} & \multicolumn{2}{|c|}{$15.65 \%$} \\
\hline SIC $6^{*}$ & \multicolumn{2}{|c|}{$21.99 \%$} & \multicolumn{2}{|c|}{$22.61 \%$} \\
\hline $\mathrm{SIC} 7^{*}$ & \multicolumn{2}{|c|}{$25.73 \%$} & \multicolumn{2}{|c|}{$32.09 \%$} \\
\hline SIC $8^{*}$ & \multicolumn{2}{|c|}{$10.68 \%$} & \multicolumn{2}{|c|}{$10.23 \%$} \\
\hline SIC $9^{*}$ & \multicolumn{2}{|c|}{$0.29 \%$} & \multicolumn{2}{|r|}{$0.17 \%$} \\
\hline
\end{tabular}

${ }^{a}$ Notes:

1. Panel A compares the characteristics of firms assigned to pro-debtor and pro-creditor judges. With the exception of the refiling rate, the two samples are almost identical.

2. Panel B compares the composition of firms by industry as defined by the first digit of their SIC code. 
Table IV

Cases by Year $^{a}$

\begin{tabular}{|c|c|c|c|c|c|c|c|c|c|}
\hline \multirow[t]{2}{*}{ Panel A } & \multicolumn{9}{|c|}{ Case Count by District: Dun \& Bradstreet } \\
\hline & $A Z$ & $C A-L A$ & $C A-N D$ & $C A-R S$ & $C A-S A$ & $C A-S V$ & $N-G A$ & $N J$ & Total \\
\hline 1998 & 64 & 34 & 90 & 25 & 45 & 29 & 36 & 18 & 260 \\
\hline 1999 & 70 & 61 & 6 & 14 & 35 & 21 & 31 & 40 & 278 \\
\hline 2000 & 91 & 80 & 6 & 25 & 48 & 37 & 44 & 47 & 378 \\
\hline 2001 & 74 & 130 & 17 & 21 & 66 & 34 & 39 & 63 & 444 \\
\hline 2002 & 32 & 59 & 9 & 18 & 33 & 20 & 39 & 55 & 265 \\
\hline 2003 & 9 & 78 & 12 & 19 & 32 & 23 & 7 & 5 & 185 \\
\hline 2004 & 0 & 22 & 3 & 12 & 12 & 5 & 0 & 0 & 54 \\
\hline Total & 340 & 464 & 62 & 134 & 271 & 169 & 196 & 228 & 1,884 \\
\hline \multirow[t]{2}{*}{ Panel B } & \multicolumn{9}{|c|}{ Case Count by District: NETS } \\
\hline & $A Z$ & $C A-L A$ & $C A-N D$ & $C A-R S$ & $C A-S A$ & $C A-S V$ & $N-G A$ & $N J$ & Total \\
\hline 1998 & 41 & 13 & 5 & 11 & 16 & 7 & 24 & 12 & 129 \\
\hline 1999 & 42 & 26 & 3 & 10 & 11 & 12 & 20 & 19 & 132 \\
\hline 2000 & 41 & 31 & 1 & 7 & 19 & 17 & 23 & 21 & 160 \\
\hline 2001 & 27 & 42 & 5 & 10 & 16 & 16 & 15 & 23 & 154 \\
\hline 2002 & 21 & 24 & 5 & 15 & 22 & 9 & 21 & 26 & 143 \\
\hline 2003 & 0 & 0 & 0 & 0 & 0 & 0 & 0 & 0 & 0 \\
\hline 2004 & 0 & 0 & 0 & 0 & 0 & 0 & 0 & 0 & 0 \\
\hline Total & 161 & 136 & 19 & 53 & 84 & 61 & 103 & 101 & 718 \\
\hline
\end{tabular}

${ }^{a}$ Notes:

1. The time variation in the number of bankruptcies in each district is due to three factors. The gradual decrease or increase in case volume is simply due to differential district time trends. The sharp decline in case volume for the final two years of our sample is largely due to variation in timeliness of data entry by the different districts. And finally in the NETS sample is simply due to the fact that we were unable to assemble a suitable panel for cases filed in more recently than 2002 . 
Table V

Frequency of Filings ${ }^{a}$

\begin{tabular}{|c|c|c|c|c|c|c|c|c|c|c|}
\hline & \multicolumn{5}{|c|}{ Dun $\&$ Bradstreet } & \multicolumn{5}{|c|}{ Sub-Sample } \\
\hline & \multicolumn{2}{|c|}{ Filing Count } & \multicolumn{3}{|c|}{ Judge Fixed Effect } & \multicolumn{2}{|c|}{ Filing Count } & \multicolumn{3}{|c|}{ Judge Fixed Effect } \\
\hline & Mean & Std. Dev. & $F(50,1763)$ & Prob $>F$ & $L R T$ & Mean & Std. Dev. & $F(48,631)$ & Prob $>F$ & $L R T$ \\
\hline CC Agreed & 0.001 & 0.023 & 1.39 & 0.04 & $>0.10$ & 0.003 & 0.055 & 0.97 & 0.54 & $>0.10$ \\
\hline CC Grant & 0.015 & 0.123 & 1.62 & 0.00 & 0.00 & 0.011 & 0.104 & 1.80 & 0.00 & 0.00 \\
\hline CC Deny & 0.149 & 0.356 & 1.19 & 0.18 & 0.00 & 0.132 & 0.338 & 2.14 & 0.00 & 0.05 \\
\hline Conv 7 & 0.038 & 0.192 & 1.31 & 0.07 & 0.00 & 0.019 & 0.136 & 1.69 & 0.00 & 0.05 \\
\hline Conv Unknown & 0.027 & 0.161 & 1.11 & 0.28 & 0.00 & 0.021 & 0.143 & 2.56 & 0.00 & $>0.10$ \\
\hline Conv Deny & 0.008 & 0.089 & 1.07 & 0.35 & $>0.10$ & 0.005 & 0.070 & 1.28 & 0.07 & $>0.10$ \\
\hline Dismiss Grant & 0.029 & 0.167 & 1.32 & 0.07 & 0.00 & 0.025 & 0.156 & 3.23 & 0.00 & $>0.10$ \\
\hline Dismiss Deny & 0.541 & 0.498 & 1.96 & 0.00 & 0.00 & 0.559 & 0.496 & 5.60 & 0.00 & 0.00 \\
\hline Exclusive Grant & 0.002 & 0.040 & 0.59 & 0.99 & $>0.10$ & 0.002 & 0.048 & 0.98 & 0.53 & $>0.10$ \\
\hline Exclusive Deny & 0.024 & 0.153 & 0.72 & 0.93 & 0.10 & 0.018 & 0.133 & 1.23 & 0.12 & 0.01 \\
\hline JudgeSub Grant & 0.000 & 0.000 & N/A & $\mathrm{N} / \mathrm{A}$ & N/A & 0.000 & 0.020 & 1.14 & 0.22 & $\mathrm{~N} / \mathrm{A}$ \\
\hline JudgeSub Deny & 0.062 & 0.240 & 1.34 & 0.06 & $>0.10$ & 0.051 & 0.219 & 2.84 & 0.00 & 0.10 \\
\hline LiftStay Grant & 0.068 & 0.253 & 1.55 & 0.01 & 0.00 & 0.048 & 0.215 & 2.26 & 0.00 & $>0.10$ \\
\hline LiftStay Deny & 0.254 & 0.436 & 1.83 & 0.00 & 0.00 & 0.167 & 0.373 & 3.43 & 0.00 & 0.00 \\
\hline Objection Debtor & 0.003 & 0.051 & 0.64 & 0.98 & 0.00 & 0.002 & 0.044 & 2.48 & 0.00 & $>0.10$ \\
\hline Objection Creditor & 0.004 & 0.065 & 0.53 & 1.00 & 0.00 & 0.005 & 0.069 & 1.64 & 0.00 & $>0.10$ \\
\hline Sale Grant & 0.003 & 0.051 & 0.50 & 1.00 & $>0.10$ & 0.004 & 0.064 & 0.86 & 0.77 & $>0.10$ \\
\hline Sale Deny & 0.012 & 0.110 & 1.03 & 0.41 & 0.00 & 0.001 & 0.094 & 2.63 & 0.00 & 0.00 \\
\hline SuaSponte & 0.006 & 0.076 & 2.94 & 0.00 & 0.10 & 0.002 & 0.048 & 7.88 & 0.00 & 0.01 \\
\hline
\end{tabular}

${ }^{a}$ Notes:

1. Summary statistics are provided for both the full Dun \& Bradstreet sample and a Dun \& Bradstreet sub-sample that drops all cases that were filed before 1998 and cases filed by firms in the top and bottom decile in yearly sales. The results of a joint $F$ test on judge fixed effects for a given filing show that fixed effects for commonly occuring filings are significant for both the full and sub-sample. 
Table VI

Random Assignment ${ }^{a}$

\begin{tabular}{|c|c|c|c|c|c|c|c|c|}
\hline \multirow{4}{*}{$\begin{array}{l}\text { Panel A } \\
\log (\text { Sales) }\end{array}$} & \multicolumn{8}{|c|}{ Judge F.E. for Sales and Employment } \\
\hline & \multicolumn{4}{|c|}{ Full Sample } & \multicolumn{4}{|c|}{$\begin{array}{c}\text { Dropping Judges } \\
\text { with < } 10 \text { Cases }\end{array}$} \\
\hline & \multicolumn{8}{|c|}{ Dunn \& Bradstreet } \\
\hline & 1884 & 1884 & 1884 & 1884 & 1851 & 1851 & 1851 & 1851 \\
\hline Number of Judges & 53 & 53 & 53 & 53 & 48 & 48 & 48 & 48 \\
\hline Prob $>$ F & 0.00 & 0.24 & 0.37 & 0.35 & 0.10 & 0.32 & 0.45 & 0.45 \\
\hline \multicolumn{9}{|l|}{ Number of Employees } \\
\hline Number of Cases & 1864 & 1864 & 1864 & 1864 & 1851 & 1851 & 1851 & 1851 \\
\hline Number of Judges & 53 & 53 & 53 & 53 & 48 & 48 & 48 & 48 \\
\hline Prob $>$ F & 0.39 & 0.97 & 0.97 & 0.98 & 0.27 & 0.93 & 0.93 & 0.93 \\
\hline $\begin{array}{l}\text { Panel B } \\
\log (\text { Sales })\end{array}$ & \multicolumn{8}{|c|}{ NETS } \\
\hline Number of Cases & 718 & 718 & 718 & 718 & 711 & 711 & 711 & 711 \\
\hline Number of Judges & 53 & 53 & 53 & 53 & 48 & 48 & 48 & 48 \\
\hline Prob $>$ F & 0.53 & 0.65 & 0.75 & 0.77 & 0.46 & 0.66 & 0.75 & 0.77 \\
\hline \multicolumn{9}{|l|}{ Number of Employees } \\
\hline Number of Cases & 1864 & 1864 & 1864 & 1864 & 1851 & 1851 & 1851 & 1851 \\
\hline Number of Judges & 53 & 53 & 53 & 53 & 48 & 48 & 48 & 48 \\
\hline Prob $>$ F & 0.41 & 0.46 & 0.46 & 0.46 & 0.32 & 0.26 & 0.27 & 0.27 \\
\hline District Trends & Yes & Yes & Yes & Yes & Yes & Yes & Yes & Yes \\
\hline Industry F.E. & No & Yes & Yes & Yes & No & Yes & Yes & Yes \\
\hline Corporation dummy & No & No & Yes & Yes & No & No & Yes & Yes \\
\hline Voluntary Filing dummy & No & No & No & Yes & No & No & No & Yes \\
\hline
\end{tabular}

${ }^{a}$ Notes:

1. The table reports the results of a joint $\mathrm{F}$ test for all judge coefficients.

2. For comparison, it should be noted that with the exception of the change in sales in years one and two post filing, and the change in employment in years one, two and three post filing the $\mathrm{F}$ test for equivalence of the judge fixed effect could be rejected at the $0 \%$ level for all our outcome variables. 
Table VII

ProDebtor Dummy Results ${ }^{a}$

\begin{tabular}{|c|c|c|c|c|c|}
\hline \multirow[t]{2}{*}{ Panel $A$} & & \multicolumn{4}{|c|}{ Pro-Debtor Dummy Coefficient } \\
\hline & & \multicolumn{2}{|c|}{ Dun $\&$ Bradstreet } & \multicolumn{2}{|c|}{ NETS } \\
\hline Refile & & \multicolumn{2}{|c|}{$\begin{array}{c}0.017 \\
(0.006)^{* *}\end{array}$} & \multicolumn{2}{|c|}{$\begin{array}{c}0.014 \\
(0.017)\end{array}$} \\
\hline Count & & \multicolumn{2}{|c|}{1,864} & \multicolumn{2}{|c|}{718} \\
\hline Log(Case Duration) & & \multicolumn{2}{|c|}{$\begin{array}{c}0.002 \\
(0.108)\end{array}$} & \multicolumn{2}{|c|}{$\begin{array}{c}0.079 \\
(0.122)\end{array}$} \\
\hline Count & & \multicolumn{2}{|c|}{1,827} & \multicolumn{2}{|c|}{704} \\
\hline Out of Business & & \multicolumn{2}{|c|}{$\begin{array}{c}0.056 \\
(0.018)^{*}\end{array}$} & \multicolumn{2}{|c|}{$\begin{array}{c}0.042 \\
(0.043)\end{array}$} \\
\hline \multirow[t]{3}{*}{ Panel B } & \multicolumn{5}{|c|}{ Panel Data } \\
\hline & \multicolumn{5}{|c|}{ Years after Initial Filing } \\
\hline & 1 & 2 & 3 & 4 & 5 \\
\hline $\begin{array}{l}\text { DEB Credit } \\
\text { Rating }\end{array}$ & & $\begin{array}{c}0.001 \\
(0.010)\end{array}$ & $\begin{array}{c}0.019 \\
(0.019)\end{array}$ & $\begin{array}{c}-0.086 \\
(0.037)^{*}\end{array}$ & $\begin{array}{c}-0.183 \\
(0.101)+\end{array}$ \\
\hline Sales & $\begin{array}{c}-0.064 \\
(0.046)\end{array}$ & $\begin{array}{l}-0.049 \\
(0.045)\end{array}$ & $\begin{array}{l}-0.090 \\
(0.059)\end{array}$ & $\begin{array}{c}-0.194 \\
(0.099)+\end{array}$ & $\begin{array}{c}-0.242 \\
(0.127)+\end{array}$ \\
\hline Employees & $\begin{array}{l}-0.040 \\
(0.041)\end{array}$ & $\begin{array}{l}-0.032 \\
(0.048)\end{array}$ & $\begin{array}{l}-0.058 \\
(0.050)\end{array}$ & $\begin{array}{l}-0.069 \\
(0.091)\end{array}$ & $\begin{array}{l}-0.014 \\
(0.130)\end{array}$ \\
\hline Paydex Min & $\begin{array}{l}-0.027 \\
(0.113)\end{array}$ & $\begin{array}{l}-0.104 \\
(0.126)\end{array}$ & $\begin{array}{l}-0.242 \\
(0.157)\end{array}$ & $\begin{array}{l}-0.081 \\
(0.137)\end{array}$ & $\begin{array}{l}-0.130 \\
(0.152)\end{array}$ \\
\hline Paydex Max & $\begin{array}{l}-0.072 \\
(0.059)\end{array}$ & $\begin{array}{l}-0.036 \\
(0.063)\end{array}$ & $\begin{array}{l}-0.092 \\
(0.120)\end{array}$ & $\begin{array}{l}-0.088 \\
(0.096)\end{array}$ & $\begin{array}{l}-0.028 \\
(0.040)\end{array}$ \\
\hline
\end{tabular}

${ }^{a}$ Notes:

1. ${ }^{+}$Significant at $10 \% ;{ }^{*}$ Significant at $5 \% ;{ }^{* *}$ Significant at $1 \%$

2. The D\&B Credit Rating was run on the Dun \& Bradstreet dataset. All other outcomes in Panel B are from the NETS dataset. 


\section{Table VIII}

ProDebtor/ProCreditor Dummy Results ${ }^{a}$

\begin{tabular}{|c|c|c|c|c|}
\hline \multirow[t]{2}{*}{ Panel $A$} & \multicolumn{2}{|c|}{ Dun $\&$ Bradstreet } & \multicolumn{2}{|c|}{ NETS } \\
\hline & ProDebtor & ProCreditor & ProDebtor & ProCreditor \\
\hline Refile & $\begin{array}{c}0.017 \\
(0.006)^{* *}\end{array}$ & $\begin{array}{l}-0.002 \\
(0.007)\end{array}$ & $\begin{array}{c}0.011 \\
(0.016)\end{array}$ & $\begin{array}{c}0.013 \\
(0.015)\end{array}$ \\
\hline Count & \multicolumn{2}{|c|}{1864} & \multicolumn{2}{|c|}{718} \\
\hline Log(Case Duration) & $\begin{array}{c}0.036 \\
(0.102)\end{array}$ & $\begin{array}{c}-0.194 \\
(0.103)+\end{array}$ & $\begin{array}{c}0.093 \\
(0.124)\end{array}$ & $\begin{array}{l}-0.067 \\
(0.122)\end{array}$ \\
\hline Count & \multicolumn{2}{|c|}{1827} & \multicolumn{2}{|c|}{704} \\
\hline Out of Business & $\begin{array}{c}0.056 \\
(0.021)^{*}\end{array}$ & $\begin{array}{l}-0.002 \\
(0.023)\end{array}$ & $\begin{array}{c}0.037 \\
(0.044)\end{array}$ & $\begin{array}{c}0.019 \\
(0.041)\end{array}$ \\
\hline Count & \multicolumn{2}{|c|}{1864} & \multicolumn{2}{|c|}{718} \\
\hline
\end{tabular}

${ }^{a}$ Notes:

1. + Significant at $10 \% ;{ }^{*}$ Significant at $5 \% ;{ }^{* *}$ Significant at $1 \%$

2. For a description of how the pro-debtor and pro-creditor dummies were constructed, please refer to Section 6 of the text. 
Table IX

Pro-Debtor Interaction Coefficients ${ }^{a}$

\begin{tabular}{|c|c|c|c|c|c|c|c|c|}
\hline \multirow[b]{2}{*}{ Pro-Debtor } & \multicolumn{2}{|c|}{$\begin{array}{c}\text { Out of } \\
\text { Business }\end{array}$} & \multicolumn{2}{|c|}{$\Delta \log ($ Sales $)$} & \multicolumn{2}{|c|}{$\begin{array}{c}\triangle P A Y D E X \\
\quad(\text { min })\end{array}$} & \multicolumn{2}{|c|}{$\begin{array}{c}\triangle P A Y D E X \\
\quad(\max )\end{array}$} \\
\hline & $\begin{array}{c}0.012 \\
(0.026)\end{array}$ & $\begin{array}{l}-0.230 \\
(0.207)\end{array}$ & $\begin{array}{l}-0.026 \\
(0.168)\end{array}$ & $\begin{array}{c}0.253 \\
(1.448)\end{array}$ & $\begin{array}{c}0.677 \\
(0.430)\end{array}$ & $\begin{array}{c}7.801 \\
(3.566)^{*}\end{array}$ & $\begin{array}{c}0.240 \\
(0.172)\end{array}$ & $\begin{array}{c}3.452 \\
(1.795)+\end{array}$ \\
\hline $\begin{array}{l}\text { Corporation } \\
P D^{*} \text { Corp }\end{array}$ & $\begin{array}{c}0.178 \\
(0.032)^{* *} \\
0.060 \\
(0.042)\end{array}$ & & $\begin{array}{c}0.012 \\
(0.085) \\
-0.068 \\
(0.189)\end{array}$ & & $\begin{array}{c}0.748 \\
(0.365)^{*} \\
-0.901 \\
(0.444)^{*}\end{array}$ & & $\begin{array}{c}0.103 \\
(0.100) \\
-0.407 \\
(0.176)^{*}\end{array}$ & \\
\hline $\begin{array}{l}\log (\text { Sales }) \\
P D^{*} \log (\text { Sales })\end{array}$ & & $\begin{array}{c}0.043 \\
(0.009)^{* *} \\
0.023 \\
(0.016)\end{array}$ & & $\begin{array}{c}-0.321 \\
(0.058)^{* *} \\
-0.033 \\
(0.109)\end{array}$ & & $\begin{array}{c}0.430 \\
(0.124)^{*} \\
-0.554 \\
(0.258)^{*}\end{array}$ & & $\begin{array}{c}0.175 \\
(0.112) \\
-0.250 \\
(0.128)+\end{array}$ \\
\hline
\end{tabular}

${ }^{a}$ Notes:

1. + Significant at $10 \% ;{ }^{*}$ Significant at $5 \% ;{ }^{* *}$ Significant at $1 \%$

2. The independent variable $\log ($ Sales) represents the yearly sales volume of a firm the year of filing.

3. Out of Business indicates whether a business is deemed a non-existent entitity within four years of filing.

4. $\triangle \log ($ Sales $)$ and $\triangle P A Y D E X$ are the difference between the value the year of filing and 4 years after filing. 
Table X

Refiling IV Results ${ }^{a}$

\begin{tabular}{|c|c|c|c|c|}
\hline \multicolumn{5}{|c|}{ Effect of judge decisions on re-filing rate } \\
\hline & \multicolumn{2}{|c|}{$O L S$} & \multicolumn{2}{|c|}{$I V$} \\
\hline Cash Collateral $^{@}$ & $\begin{array}{c}0.008 \\
(0.023)\end{array}$ & $\begin{array}{c}0.008 \\
(0.023)\end{array}$ & $\begin{array}{c}0.505 \\
(0.190)^{* *}\end{array}$ & $\begin{array}{c}0.507 \\
(0.190)^{* *}\end{array}$ \\
\hline Convert to $\mathrm{Ch} .7$ & $\begin{array}{c}-0.014 \\
(0.018)\end{array}$ & $\begin{array}{r}-0.015 \\
(0.018\end{array}$ & $\begin{array}{c}-0.218 \\
(.159)\end{array}$ & $\begin{array}{c}-0.223 \\
(.160)\end{array}$ \\
\hline Dismiss Case & $\begin{array}{c}-0.22 \\
(0.017)\end{array}$ & $\begin{array}{c}-0.22 \\
(0.017)\end{array}$ & $\begin{array}{c}0.170 \\
(0.127)\end{array}$ & $\begin{array}{l}0.165 \\
(.127)\end{array}$ \\
\hline Extend Exclusivity Period ${ }^{@}$ & $\begin{array}{l}-0.004 \\
(0.052)\end{array}$ & $\begin{array}{l}-0.004 \\
(0.052)\end{array}$ & $\begin{array}{c}1.057 \\
(.567)^{* *}\end{array}$ & $\begin{array}{c}1.069 \\
(.567)^{* *}\end{array}$ \\
\hline Lift Automatic Stay & $\begin{array}{l}-0.007 \\
(0.012)\end{array}$ & $\begin{array}{l}-0.007 \\
(0.012)\end{array}$ & $\begin{array}{l}-0.100 \\
(0.098)\end{array}$ & $\begin{array}{l}-0.097 \\
(0.098)\end{array}$ \\
\hline Sale of Asset ${ }^{@}$ & $\begin{array}{l}-0.022 \\
(0.038)\end{array}$ & $\begin{array}{l}-0.022 \\
(0.038)\end{array}$ & $\begin{array}{l}-0.282 \\
(0.465)\end{array}$ & $\begin{array}{c}-0.284 \\
(0.466)\end{array}$ \\
\hline Log(Sales) & & $\begin{array}{c}-0.001 \\
(0.002)\end{array}$ & & $\begin{array}{l}-0.001 \\
(0.002)\end{array}$ \\
\hline Observations & 4857 & 4857 & 4823 & 4823 \\
\hline
\end{tabular}

${ }^{a}$ Notes:

1. The table shows the effect of each action instrumented by the judge's fixed effects on re-filing rates. The dependent variable has been detrended at the district * year level. Standard errors are in parenthesis.

2. @ Debtor filed actions

3. + Significant at $10 \% ;{ }^{*}$ Significant at $5 \% ;{ }^{* *}$ Significant at $1 \%$ 
Table XI

Sample of Judge Fixed Effects ${ }^{a}$

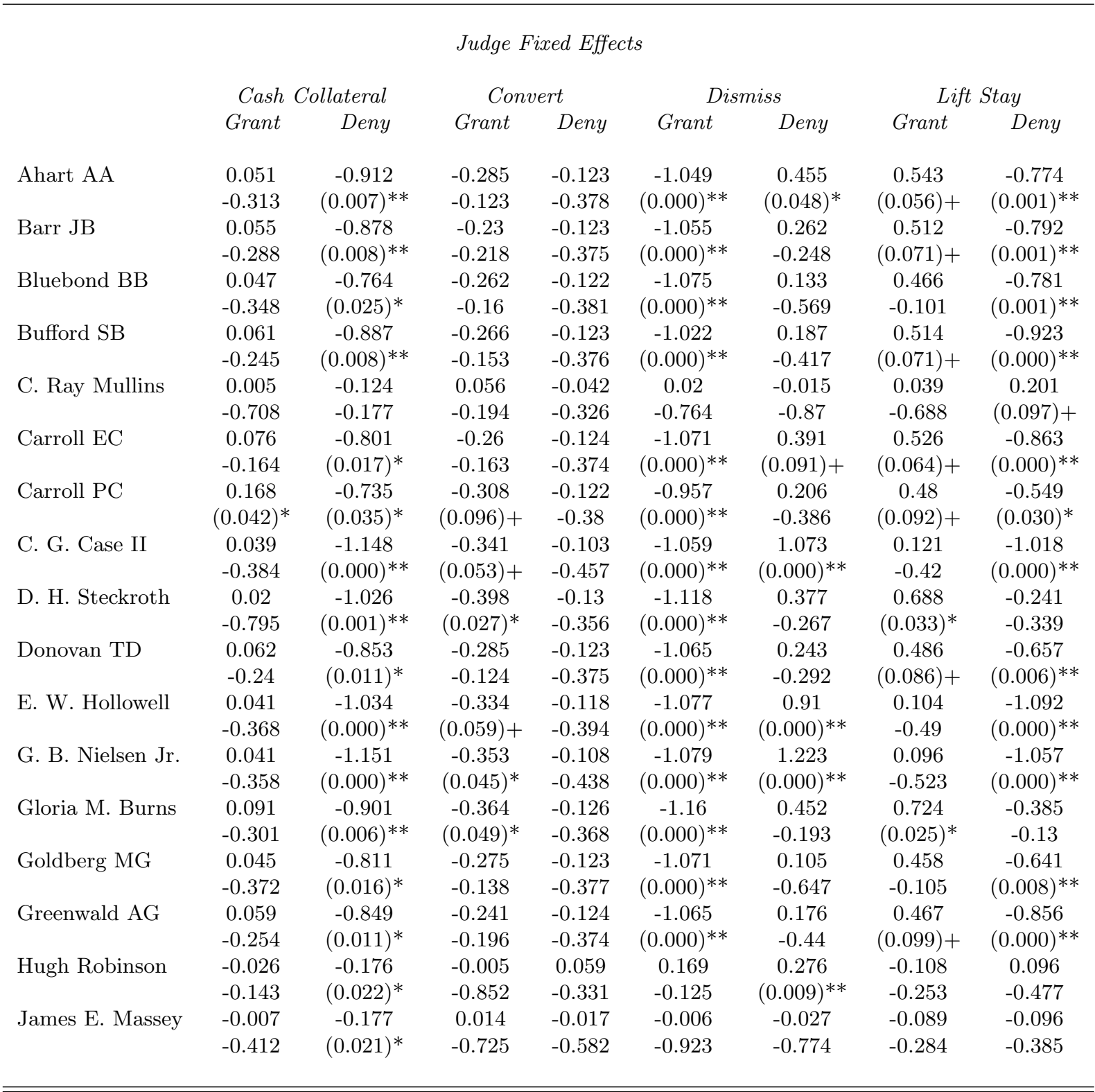

${ }^{a}$ Notes:

1. This table shows a sampling of some of the judge fixed effects (i.e. a judge's propensity for various actions) controlling for SIC and district * year trends. Standard errors are in parenthesis. The results have proven quite robust to variation in the control variables (Sales, Employees, Voluntary, Corporation) and to the use of subsets of the data (e.g. dropping districts, dropping low volume judges, dropping cases that are dismissed or converted).

2. ${ }^{+}$Significant at $10 \% ;{ }^{*}$ Significant at $5 \% ;{ }^{* *}$ Significant at $1 \%$ 
